\title{
Echocardiographic Assessment of the Cardiac Amyloidoses
}

\author{
Jun Koyama, MD, PhD; Shu-ichi Ikeda, MD, PhD; Uichi Ikeda, MD, PhD
}

\begin{abstract}
Cardiac amyloidosis is a cardiomyopathy characterized by increased left ventricular (LV) wall thickness and normal or decreased LV cavity size. Congestive heart failure in cardiac amyloidosis is generally considered a predominantly diastolic phenomenon, with systolic dysfunction only occurring in late-stage disease. Echocardiography is a noninvasive, reproducible method of assessing cardiac features and function in cardiac amyloidosis, and some echocardiographic indices are prognostic for the amyloidoses, with M-mode and 2-dimensional echocardiography able to detect increased LV wall thickness. Moreover, Doppler flow measurements can incrementally assess diastolic LV dysfunction, which is characteristic of cardiac amyloidosis, and provide important prognostic information. Additionally, tissue Doppler imaging can detect subtle changes in both systolic and diastolic LV function, which cannot be detected by Doppler flow measurements, and LV longitudinal strain assessed by color tissue Doppler and speckle tracking echocardiography can provide more accurate LV functional and prognostic information than tissue Doppler imaging. This review describes the advances in echocardiography and its crucial role in the diagnosis and management of cardiac amyloidosis. (Circ J 2015; 79: 721-734)
\end{abstract}

Key Words: Cardiac amyloidosis; Doppler imaging; Echocardiography

\section{Overview of Cardiac Amyloidosis}

Cardiac amyloidosis is a manifestation of one of several systemic amyloidoses. ${ }^{1,2}$ This disease affects multiple organs and tissues with extracellular deposition of pathologic, insoluble fibrillar proteins. Cardiac involvement in the amyloidoses may be the predominant feature and its relative predominance varies with the type of amyloidosis.

The main forms of amyloidosis that affect the heart are as follows.

(1) Light-chain amyloidosis (AL or primary): this type of amyloidosis is caused by immunoglobulin light-chain usually associated with plasma cell dyscrasia, but usually not associated with multiple myeloma. It affects heart, kidney, liver, peripheral/autonomic nerves, soft tissue, and the gastrointestinal system. Heart disease occurs in one-third to half of AL patients, and heart failure tends to progress rapidly once the heart is affected and has a very poor prognosis. The major treatment for this disease is chemotherapy.

(2) Transthyretin-associated amyloidoses (ATTR): these include 2 types of amyloidosis.

Mutated type of transthyretin-associated amyloidosis (ATTRm) is also called "familial type of amyloid polyneuropathy (FAP)". This type is caused by mutant transthyretin produced in the liver. It affects peripheral/ autonomic nerves and the heart. This disease is autosomal dominant and amyloid deposition derives from a mixture of mutant and wild-type transthyretin. The treat- ments are liver transplantation and new drugs (diflunisal and tafamidis) to stabilize transthyretin. ${ }^{3}$ If heart involvement presents beforehand, cardiac amyloidosis may progress despite liver transplantation in some cases. In V30M-type ATTRm, it was previously thought that patients in endemic areas rarely suffered from cardiac amyloidosis. However, it has been recently noted that some ATTRm patients with V30M type developed the disease at a later age and suffered severe cardiac amyloidosis with congestive heart failure in Japan. Most of them originated from nonendemic areas.,

Another type of ATTR amyloidosis is associated with wild-type transthyretin (ATTRwt). This type of amyloidosis is also known as senile systemic amyloidosis (SSA). The main involved organ is the heart. This type is almost exclusively found in elderly men (male: female $=20: 1 \sim 50: 1)$ and the symptoms are slowly progressive. $^{3}$

(3) Secondary amyloidosis: this type of amyloidosis is caused by serum amyloid A and also called AA amyloidosis. It is seen in association with juvenile or adult rheumatoid arthritis and other rheumatic disorders such as ankylosing spondylitis, as well as with inflammatory bowel disease. Hepatic and renal amyloid deposition dominates the clinical features, and clinical heart disease related to cardiac amyloidosis is rare. Treatment is to heal the underlying inflammatory process.

The purpose of this review is to describe the advances in echocardiographic assessment and to discuss its crucial role in

Received January 5, 2015; revised manuscript received February 10, 2015; accepted February 12, 2015; released online March 12 , 2015

Department of Cardiovascular Medicine (J.K., U.I.), Department of Medicine (Neurology and Rheumatology) (S.I.), Shinshu University School of Medicine, Matsumoto, Japan

Mailing address: Jun Koyama, MD, PhD, Department of Cardiovascular Medicine, Shinshu University School of Medicine, 3-1-1 Asahi, Matsumoto 390-8621, Japan. E-mail: jkoyama@shinshu-u.ac.jp

ISSN-1346-9843 doi:10.1253/circj.CJ-14-1425

All rights are reserved to the Japanese Circulation Society. For permissions, please e-mail: cj@j-circ.or.jp 
Table. Echocardiographic Studies of Patients With Cardiac Amyloidosis

\begin{tabular}{|c|c|c|c|}
\hline $\begin{array}{l}\text { Authors } \\
\text { M-mode echoc }\end{array}$ & $\begin{array}{l}\text { Year / Journal } \\
\text { ardiography }\end{array}$ & $\begin{array}{l}\text { No. of amyloidosis } \\
\text { patients }\end{array}$ & Clinical and echocardiographic findings \\
\hline Chew et $a^{6}$ & $\begin{array}{c}1975 / \\
\text { Am J Cardiol }\end{array}$ & $3(\mathrm{NA})$ & $\begin{array}{l}\text { Normal LV dimension in diastole, diminished amplitude of excursion, } \\
\text { increased systolic dimension, and pericardial effusion }\end{array}$ \\
\hline Child et $\mathrm{al}^{7}$ & 1976 / Chest & $\begin{array}{l}5(\mathrm{MM}) / \\
1 \text { (ankylosing spondylitis) / } \\
1 \text { (unknown) }\end{array}$ & $\begin{array}{l}\text { Symmetrically increased LV wall thickness in the absence of hypertension or } \\
\text { aortic valvular disease, hypokinesia and decreased systolic thickening of the } \\
\text { LV wall, and small-to-normal sized LV cavity }\end{array}$ \\
\hline Borer et $\mathrm{a}^{8}$ & $\begin{array}{c}1977 / \\
\text { Am J Cardiol }\end{array}$ & $\begin{array}{l}4 \text { (AL) / } 10 \text { (idiopathic } \\
\text { hypereosinophilic } \\
\text { syndrome) / } \\
5 \text { (iron overload) }\end{array}$ & $\begin{array}{l}\text { (1) Thickened LV free wall and septum, }(2) \text { increased LV mass, (3) septal/ } \\
\text { posterobasal free wall thickness ratio }<1.3 \text {, (4) increased maximal left atrial } \\
\text { transverse dimension, (5) reduced mitral valve closure }(E-F) \text { slope, and }(6) \\
\text { preserved LV ejection fraction }>60 \%\end{array}$ \\
\hline Child et $\mathrm{al}^{9}$ & $\begin{array}{c}1979 / \\
\text { Am J Cardiol }\end{array}$ & $6(\mathrm{NA})$ & Increased RV anterior wall thickness \\
\hline Child et al ${ }^{10}$ & $\begin{array}{l}1981 / \\
\text { Am Heart J }\end{array}$ & $8(\mathrm{NA})$ & $\begin{array}{l}\text { Increased mitral E point to ventricular septal separation and mitral E point to } \\
\text { ventricular septal separation/LV end-diastolic dimension ratio }\end{array}$ \\
\hline $\begin{array}{l}\text { St John } \\
\text { Sutton } \\
\text { et al }{ }^{11}\end{array}$ & $\begin{array}{c}1982 / \\
\text { Circulation }\end{array}$ & $19(\mathrm{AL}) / 1(\mathrm{MM})$ & $\begin{array}{l}\text { (1) Normal or decreased LV cavity size, (2) decreased peak rate of diastolic } \\
\text { cavity filling, (3) prolonged isovolumic relaxation, (4) decreased fractional } \\
\text { shortening and peak rate of circumferential fiber shortening, and (5) decreased } \\
\text { peak rates of both systolic thickening and diastolic thinning of the septum } \\
\text { and posterior LV wall }\end{array}$ \\
\hline $\begin{array}{l}\text { Roberts } \\
\text { et } \mathrm{al}^{12}\end{array}$ & $\begin{array}{c}1983 / \\
\text { Am J Cardiol }\end{array}$ & $11(\mathrm{AL})$ & $\begin{array}{l}\text { Comparisons of echocardiographic and necropsy findings revealed (1) thick } \\
\text { LV wall and (2) small LV cavity in endstage cardiac amyloid patients }\end{array}$ \\
\hline
\end{tabular}

2D echocardiography
Siqueira-
$1981 /$
Filho et $\mathrm{al}^{13}$
Circulation
$23(\mathrm{AL}) / 5(\mathrm{MM})$

2D echocardiography+ECG voltage

$\begin{array}{lcc}\begin{array}{l}\text { Carroll } \\ \text { et al }{ }^{14}\end{array} & 1982 / & 14(\mathrm{AL}) \\ \text { Simons } & 1992 / & 13(\mathrm{AL}) / 2(\mathrm{AA}) \\ \text { et al }{ }^{15} & \text { Am J Cardiol } & \end{array}$

$\begin{array}{lcc}\begin{array}{l}\text { Hamer } \\ \text { et al }\end{array} & \begin{array}{c}1992 / \\ \text { Eur Heart J }\end{array} & 30(\mathrm{AA}) / 24(\mathrm{AL}) \\ \begin{array}{l}\text { Rahman } \\ \text { et al }{ }^{17}\end{array} & \begin{array}{c}2004 / \\ \text { J Am Coll Cardiol }\end{array} & 58(\mathrm{NA})\end{array}$

\section{Myocardial texture characterization}

$\begin{array}{lcc}\begin{array}{l}\text { Bhandari } \\ \text { et al }\end{array} & \begin{array}{c}1983 / \\ \text { Am J Cardiol }\end{array} & 7 \text { (NA) } \\ \begin{array}{l}\text { Nicolosi } \\ \text { et al }{ }^{19}\end{array} & \begin{array}{c}1984 / \\ \text { Circulation }\end{array} & 11 \text { (NA) }\end{array}$

$\begin{array}{lcc}\text { Falk et al }{ }^{20} & \begin{array}{c}1987 / \\ \text { Am J Cardiol }\end{array} & 15(\mathrm{AL}) \\ \begin{array}{l}\text { Pinamonti } \\ \text { et al }\end{array} & \begin{array}{c}1989 / \\ \text { J Am Coll Cardiol }\end{array} & 6 \text { (NA) }\end{array}$

Myocardial scintigraphy vs. echocardiography

$\begin{array}{lcc}\text { Falk et } \mathrm{al}^{22} & \begin{array}{c}1983 / \\ \text { Am J Cardiol }\end{array} & 20(\mathrm{AL}) \\ \begin{array}{l}\text { Eriksson } \\ \text { et al }{ }^{23}\end{array} & \begin{array}{c}1984 / \\ B r \text { Heart } J\end{array} & 12(\mathrm{FAP}) \\ \begin{array}{l}\text { Fournier } \\ \text { et al }{ }^{24}\end{array} & \begin{array}{c}1993 / \\ \text { Am J Cardiol }\end{array} & 15 \text { (FAP) }\end{array}$

(1) Thickened papillary muscles, (2) thickened valves, (3) better appreciation of the thickened RV wall, and (4) granular sparkling appearance of the thickened cardiac walls

Inverse correlation between voltage and muscle cross-sectional area

Voltage/mass relation diagrams appeared to be a promising and more sensitive noninvasive diagnostic technique of cardiac amyloidosis compared with both myocardial technetium uptake and echocardiographic observation of sparkling appearance

Voltage/mass index abnormalities found in $3 / 30 \mathrm{AA}$ patients and 13/24 AL patients

Among 196 endomyocardial biopsy specimens from patients with suspected amyloidosis, 58 specimens were positive

A combination of a low voltage and increased LV thickness produced the most statistically useful model

Very bright or highly refractile echoes in the myocardium were present in all patients with amyloidosis; however, the presence of this pattern was not specific for cardiac amyloidosis

Qualitative evaluation of 2D echocardiographic images identified changes in myocardial wall echogenicity, which correlated with positive gingival biopsy results for amyloidosis in 11/15 patients

Combination of increased myocardial echogenicity and increased atrial thickness was $60 \%$ sensitive and $100 \%$ specific for the diagnosis of amyloidosis

Higher entropy was observed in cardiac amyloidosis patients compared with normal controls

Increased wall thickness correlated with myocardial pyrophosphate uptake

Cross-sectional echocardiography was superior to technetium-99 m pyrophosphate scintigraphy for detecting cardiac involvement in familial amyloidosis with polyneuropathy

Scintigraphy uptake index, calculated as cardiac activity after background subtraction/liver activity, clearly differed between echocardiographic cardiac amyloidosis and nondetectable cardiac amyloidosis cases 
2D echocardiographic assessment and prognosis

Falk et $\mathrm{a}^{25} \quad 1984 / 27$ (AL) / 6 (FAP)

J Am Coll Cardiol

\begin{tabular}{|c|c|c|}
\hline $\begin{array}{l}\text { Cueto-Garcia } \\
\text { et al }{ }^{26}\end{array}$ & 1985 / & $132(\mathrm{AL})$ \\
\hline $\begin{array}{l}\text { Hongo } \\
\text { et } \mathrm{al}^{27}\end{array}$ & $\begin{array}{c}1986 / \\
\text { Circulation }\end{array}$ & 28 (FAP) \\
\hline $\begin{array}{l}\text { Kristen } \\
\text { et al }{ }^{28}\end{array}$ & $\begin{array}{l}2007 \text { / } \\
\text { Eur J Heart Fail }\end{array}$ & $43(\mathrm{AL}) / 16(\mathrm{FAP})$ \\
\hline $\begin{array}{l}\text { Dubrey } \\
\text { et al }{ }^{29}\end{array}$ & $\begin{array}{c}1997 / \\
\text { Am Heart J }\end{array}$ & $133(\mathrm{AL})$ \\
\hline
\end{tabular}

\section{Doppler echocardiography}

$\begin{array}{lcc}\begin{array}{l}\text { Kinoshita } \\ \text { et al }\end{array} & \begin{array}{c}1989 / \\ \text { Br Heart J }\end{array} & 12 \text { (FAP) } \\ \text { Klein et al }^{31} & \begin{array}{c}1989 / \\ J \text { Am Coll Cardiol }\end{array} & 64 \text { (AL) } \\ \text { Klein et al }{ }^{32} & 1990 / & 41(\mathrm{AL}) \\ & J \text { Am Coll Cardiol } & \end{array}$

\begin{tabular}{|c|c|}
\hline Klein et $\mathrm{al}^{33}$ & $\begin{array}{c}1990 / \\
J \text { Am Coll Cardiol }\end{array}$ \\
\hline
\end{tabular}

$\begin{array}{lcr}\begin{array}{l}\text { Dubrey } \\ \text { et } \mathrm{a}^{34}\end{array} & 1997 / \text { Heart } & 24 \text { (AL) / } 12 \text { (FAP) } \\ \begin{array}{l}\text { Murphy } \\ \text { et a }{ }^{35}\end{array} & \begin{array}{c}2000 / \\ \text { Am J Cardiol }\end{array} & 20(\mathrm{AL})\end{array}$

2D/Doppler echocardiography and patient prognosis

\begin{tabular}{|c|c|c|}
\hline Patel et $\mathrm{al}^{36}$ & $\begin{array}{c}1997 / \\
\text { Am J Cardiol }\end{array}$ & $37(\mathrm{AL})$ \\
\hline Klein et $\mathrm{al}^{37}$ & $\begin{array}{c}1991 / \\
\text { Circulation }\end{array}$ & $63(\mathrm{AL})$ \\
\hline Tei et $\mathrm{al}^{39}$ & $\begin{array}{c}1996 / \\
\text { J Am Coll Cardiol }\end{array}$ & $39(\mathrm{AL}) / 3(\mathrm{FAP}) / 3(\mathrm{SSA})$ \\
\hline $\mathrm{Ng}$ et $\mathrm{al}^{40}$ & $\begin{array}{c}2005 / \\
\text { Arch Intern Med }\end{array}$ & $18(\mathrm{SSA}) / 18(\mathrm{AL})$ \\
\hline $\begin{array}{l}\text { Migrino } \\
\text { et al }\left.\right|^{41}\end{array}$ & $\begin{array}{c}2009 / \\
J \text { Am Soc } \\
\text { Echocardiogr }\end{array}$ & $42(\mathrm{AL})$ \\
\hline $\begin{array}{l}\text { Rapezzi } \\
\text { et } \mathrm{al}^{42}\end{array}$ & $\begin{array}{c}2009 / \\
\text { Circulation }\end{array}$ & $\begin{array}{c}157 \text { (AL) / } 61 \text { (ATTRm) / } \\
15 \text { (ATTRwt) }\end{array}$ \\
\hline
\end{tabular}

$\begin{array}{lcc}\text { Pinney } & 2013 / & 102(\mathrm{SSA}) / 36(\mathrm{AL}) \\ \text { et } \mathrm{a}^{43} & \mathrm{~J} \text { Am Heart } \\ & \text { Assoc } & \end{array}$

Presence of cardiac arrhythmia correlated with heart failure and, more strongly, with abnormal echocardiography findings; 4 sudden deaths, all in patients with an abnormal echocardiograms and complex ventricular arrhythmias

Survival was negatively influenced by both greater wall thickness and reduced systolic function (fractional shortening)

Amyloid heart disease in patients with FAP develops slowly but progressively

Low-voltage pattern on ECG and the LV ejection fraction allow identification of the patients at highest risk of death

Utility of echocardiography, Holter recording, 12-lead ECG, and signal-averaged electrocardiograms analyzed

Both abnormal echocardiograms and signal-averaged electrocardiograms predictive of all-cause cardiac death and sudden cardiac death

Further, abnormal signal-averaged electrocardiograms were also independent predictors of sudden death in patients with abnormal echocardiograms

Ratio of atrial peak flow velocity to early diastolic peak flow velocity significantly greater in patients than in control subjects, and the ratio was significantly related to LV posterior wall thickness

In advanced amyloidosis, a restrictive filling pattern with a markedly shortened deceleration time, decreased pulmonary vein peak systolic flow, and increased diastolic flow velocity were noted compared with normal values

Right ventricular inflow, superior vena cava, and hepatic vein flow velocities were assessed by pulsed wave Doppler ultrasound measurements together with respiratory monitoring

Patients were divided into 2 groups based on the RV free wall thickness: $<7 \mathrm{~mm}$ and $\geq 7 \mathrm{~mm}$ in Groups 1 and 2, respectively

Group 1 showed increased peak late flow velocity and a decreased E/A velocity ratio; Group 2 showed a restrictive pattern

Patients with a mean LV thickness $<15 \mathrm{~mm}$ (early group) showed significant changes in the E/A ratio during the follow-up period; 7 patients in this group showed changes from an abnormal relaxation or "normal" pattern to one of restriction, which coincided with increased symptoms in 6 of these patients Echocardiograms morphologically indistinguishable between AL and FAP patients, whereas low-voltage electrocardiograms $(<0.5 \mathrm{mV})$ were more commonly observed in AL than in FAP patients

1 -year survival for the familial and AL forms was $92 \%$ and $38 \%$, respectively, with virtually all deaths from cardiac causes

Noninvasively derived left atrial kinetic energy, which was calculated from the formula $1 / 2 \mathrm{mv}^{2}$, where $\mathrm{m}=$ the product of the mean left atrial stroke volume (in $\mathrm{cm}^{3}$ ) and blood density $(1.06 \mathrm{~g} / \mathrm{ml}$ ), and $\mathrm{v}=$ mean transmitral Doppler A-wave velocity $(\mathrm{cm} / \mathrm{s})$, was found to be severely impaired in $A L$ amyloidosis once ventricular infiltration was apparent upon echocardiography

Using 2D and Doppler echocardiography, RV dilation (LV/RV area ratio $\leq 2$ ) was assessed - ventricular area ratio $\leq 2$ remained the only independent predictor of survival

Doppler-derived LV diastolic filling variables (transmitral E-wave deceleration time $<150 \mathrm{~ms}$, E/A ratio) found to be important predictors of survival in cardiac amyloidosis

In a multivariate stepwise regression analysis, NYHA functional class and the proposed index, combining systolic and diastolic time intervals, were the only independent predictors of survival

SSA is characterized by amyloidosis clinically limited to the heart. In contrast to the rapid progression of heart failure in AL amyloidosis, SSA results in slowly progressive heart failure, despite SSA being associated with a thicker LV wall and older patient age

Among 2D/Doppler flow (mitral and LV outflow tract flow) and several clinical parameters, only ejection time and alkaline phosphatase showed incremental value to heart failure class in predicting mortality

At diagnosis, the mean LV wall thickness was higher in ATTRwt than in ATTRm and AL patients

LVEF moderately depressed in ATTRwt but not in AL or ATTRm

ATTRm less frequently displayed low voltage-mass ratio, and was found to be a strong favorable predictor of survival, whereas ATTRwt predicted freedom from major cardiac events

SSA patients showed thicker LV walls, lower E/e', and longer transmitral early filling wave deceleration time

No echocardiographic parameters associated with poorer survival in SSA patients 


\begin{tabular}{|c|c|c|}
\hline \multicolumn{3}{|c|}{ Pulsed tissue Doppler imaging } \\
\hline $\begin{array}{l}\text { Koyama } \\
\text { et } \mathrm{al}^{44}\end{array}$ & $\begin{array}{c}2002 / \\
\text { Am J Cardiol }\end{array}$ & $86(\mathrm{AL})$ \\
\hline Palka et al ${ }^{45}$ & $\begin{array}{c}2002 / \\
J \text { Am Soc } \\
\text { Echocardiogr }\end{array}$ & $36(\mathrm{AL})$ \\
\hline $\begin{array}{l}\text { Koyama } \\
\text { et } \mathrm{al}^{46}\end{array}$ & $\begin{array}{c}2004 \text { / } \\
\text { J Am Soc } \\
\text { Echocardiogr }\end{array}$ & $33(\mathrm{AL})$ \\
\hline $\begin{array}{l}\text { Perugini } \\
\text { et } \mathrm{al}^{47}\end{array}$ & $\begin{array}{c}2005 / \\
\text { Am J Cardiol }\end{array}$ & $15(\mathrm{AL}) / 1$ (FAP) \\
\hline $\begin{array}{l}\text { Al-Zahrani } \\
\text { et } \mathrm{al}^{48}\end{array}$ & $\begin{array}{c}2009 / \\
\text { J Am Soc } \\
\text { Echocardiogr }\end{array}$ & $238(A L)$ \\
\hline \multicolumn{3}{|c|}{ Color-coded tissue Doppler imaging } \\
\hline Oki et al ${ }^{49}$ & $\begin{array}{c}2004 / \\
A m \text { J Cardiol }\end{array}$ & $10(\mathrm{AL})$ \\
\hline
\end{tabular}

\begin{tabular}{|c|c|c|}
\hline $\begin{array}{l}\text { Koyama } \\
\text { et al }{ }^{50}\end{array}$ & $\begin{array}{c}2002 / \\
\text { Circulation }\end{array}$ & $208(\mathrm{AL})$ \\
\hline
\end{tabular}

\begin{tabular}{|c|c|c|}
\hline \multicolumn{3}{|c|}{ Strain Doppler imaging } \\
\hline $\begin{array}{l}\text { Koyama } \\
\text { et al }\left.\right|^{51}\end{array}$ & $\begin{array}{c}2003 / \\
\text { Circulation }\end{array}$ & $97(\mathrm{AL})$ \\
\hline $\begin{array}{l}\text { Bellavia } \\
\text { et al }{ }^{52}\end{array}$ & $\begin{array}{c}2007 / \\
J \text { Am Soc } \\
\text { Echocardiogr }\end{array}$ & $103(\mathrm{AL})$ \\
\hline $\begin{array}{l}\text { Ogiwara } \\
\text { et } \mathrm{al}^{53}\end{array}$ & $\begin{array}{c}2005 / \\
\text { Am J Cardiol }\end{array}$ & $14(\mathrm{AL}) / 14(\mathrm{FAP})$ \\
\hline $\begin{array}{l}\text { Bellavia } \\
\text { et al }{ }^{54}\end{array}$ & $\begin{array}{c}2008 / \\
\text { Am J Cardiol }\end{array}$ & $42(A L)$ \\
\hline
\end{tabular}

\section{Strain Doppler imaging as a prognostic factor}

$\begin{array}{lcc}\begin{array}{l}\text { Bellavia } \\ \text { et al }{ }^{55}\end{array} & \begin{array}{c}2010 / \\ \text { J Am Soc } \\ \text { Echocardiogr }\end{array} & 249 \text { (AL) } \\ \begin{array}{l}\text { Koyama } \\ \text { et al }{ }^{56}\end{array} & \begin{array}{c}2010 / \\ \text { JACC Cardiovasc } \\ \text { Imaging }\end{array} \\ \begin{array}{l}\text { Bellavia } \\ \text { et al }{ }^{57}\end{array} & \begin{array}{c}2012 \text { / Eur Heart } \\ \text { J Cardiovasc } \\ \text { Imaging }\end{array} & 249(\mathrm{AL}) \\ & & \end{array}$

Intracardiac thrombus in cardiac amyloidosis
Dubrey
$1995 /$
et al ${ }^{58}$
Br Heart J
$3(\mathrm{AL})$

$\begin{array}{ccc}\text { Feng et al }{ }^{59} & 2007 / & 55(\mathrm{AL}) / 61 \text { (others) } \\ & \begin{array}{c}\text { Circulation } \\ 2009 /\end{array} & 80(\mathrm{AL}) / 56(\mathrm{SSA}) / \\ \text { Feng et al } & \text { Circulation } & 17 \text { (FAP) / 3 (secondary) }\end{array}$

Cardiac amyloidosis found to be characterized by an initial impairment in early cardiac relaxation, whereas congestive heart failure was associated with impairments in peak systolic wall motion velocities, most prominently seen in the longitudinal axis

Peak lateral and medial mitral annulus velocities and color M-mode tissue Doppler of the LV posterior wall (for measurements of mean myocardial velocities and myocardial velocity gradient) differentiated patients with cardiac amyloidosis from control patients with a fair overall accuracy Longitudinal myocardial velocity gradients as the differences between basal and mid-myocardial velocities using pulsed tissue Doppler imaging were examined

Longitudinal myocardial velocity gradients could sensitively detect myocardial abnormalities compared with single-point analysis of pulsed tissue Doppler imaging

LV long-axis function was depressed in all patients (100\%) with cardiac amyloidosis compared with only $36 \%$ of patients with idiopathic restrictive cardiomyopathy

Even when compared with diastolic color Doppler myocardial imaging measurements, standard pulsed wave tissue Doppler imaging of the mitral annulus was found to be the most accurate diastolic measure to detect early LV dysfunction in patients with $A L$

velocity gradient from the myocardial velocity profile, derived from color-coded tissue Doppler imaging, showed a characteristic serrated pattern in all patients with cardiac amyloidosis, but not in any other patient group (hypertensive heart and hypertrophic cardiomyopathy patients)

\section{acterization}

Cycle-dependent variations of myocardial integrated backscatter were studied and multivariate analysis revealed that this parameter at the LV posterior wall was the only independent predictor of both cardiac and overall deaths

Cardiac amyloidosis characterized by an early impairment in systolic function at a time when fractional shortening remains normal

This abnormality precedes the onset of congestive heart failure and can be detected by strain and strain rate imaging but is not apparent by tissue velocity imaging

Longitudinal systolic strain most accurately detected longitudinal systolic dysfunction in AL amyloidosis and best differentiated between patients with advanced cardiac amyloidosis with increased LV thickness and patients with AL with normal wall thickness

Strain Doppler imaging could detect a difference in LV function between FAP and $A L$ amyloidosis, which cannot be distinguished by standard echocardiographic parameters even though both the severity of congestive heart failure and the rate of cardiac mortality are much lower in FAP patients

Peak systolic strain rate and systolic strain could detect impaired LV systolic function in $\mathrm{AL}$ amyloidosis patients with no evidence of cardiac involvement by standard 2D and Doppler echocardiography

Multivariate analysis identified the following independent poor predictors of clinical outcome in patients with AL amyloidosis: NYHA class III or IV, presence of pleural effusion, brain natriuretic peptide level $>493 \mathrm{pg} / \mathrm{ml}$, ejection time $<273 \mathrm{~ms}$, and peak longitudinal systolic basal anteroseptal strain $\geq-7.5 \%$

Mean basal LV longitudinal strain is a powerful predictor of clinical outcome and is superior to standard 2D echocardiographic, Doppler flow measurements, and simple tissue velocity indexes

RV function assessed by Doppler myocardial imaging can also identify early impairment of cardiac function and stratify risk of death in patients with $\mathrm{AL}$ amyloidosis

Severe atrial and ventricular infiltration by amyloid may result in mechanical atrial standstill with resultant thrombus formation, and patients with severe cardiac amyloidosis may require anticoagulation therapy when atrial function is impaired

AL type and LV diastolic dysfunction were found to be independently associated with the risk of thromboembolism

Atrial fibrillation, poor LV diastolic function, and lower left atrial appendage emptying velocity were independently associated with increased risk for intracardiac thrombosis, whereas anticoagulation therapy was associated with a significantly decreased risk

(Table continued the next page.) 


\begin{tabular}{|c|c|c|c|}
\hline \multicolumn{4}{|c|}{ Speckle tracking echocardiography } \\
\hline $\begin{array}{l}\text { Modesto } \\
\text { et al }{ }^{61}\end{array}$ & $\begin{array}{l}2006 \text { / Eur J } \\
\text { Echocardiogr }\end{array}$ & $17(\mathrm{AL})$ & $\begin{array}{l}\text { 2D strain echocardiography values correlated closely with tissue Doppler- } \\
\text { derived strain echocardiography values ( } r=0.94 \text { and } 0.96 \text { for strain rate and } \\
\text { strain, respectively) }\end{array}$ \\
\hline Sun et $\mathrm{al}^{62}$ & $\begin{array}{l}2009 / \\
\text { Am J Cardiol }\end{array}$ & 12 & $\begin{array}{l}\text { Cardiac amyloid profoundly alters all strain parameters (longitudinal, circum- } \\
\text { ferential, and radial strain) compared with other causes of LV hypertrophy }\end{array}$ \\
\hline $\begin{array}{l}\text { Di Bella } \\
\text { et al } 63\end{array}$ & 2011 / Circ J & 11 (ATTR) & $\begin{array}{l}\text { Epicardial circumferential strain was significantly lower in ATTR cardiac } \\
\text { amyloidosis than in hypertrophic cardiomyopathy patients }\end{array}$ \\
\hline $\begin{array}{l}\text { Kusunose } \\
\text { et } \mathrm{al}^{64}\end{array}$ & 2010 / Circ J & $1(\mathrm{AA})$ & $\begin{array}{l}\text { Peak systolic radial strain and strain rate can be used to identify the LV } \\
\text { segments with cardiac involvement by amyloid, as confirmed by cardiac } \\
\text { magnetic resonance imaging, in a patient with secondary (AA) amyloidosis }\end{array}$ \\
\hline Liu et $\mathrm{al}^{65}$ & $\begin{array}{l}2013 \text { / Circ } \\
\text { Cardiovasc } \\
\text { Imaging }\end{array}$ & $25(\mathrm{AL})$ & $\begin{array}{l}\text { Septal longitudinal base-to-apex strain gradient combined with a short } \\
\text { E-wave deceleration time was a good diagnostic parameter for differentiat- } \\
\text { ing cardiac amyloidosis from other causes of concentric LV hypertrophy }\end{array}$ \\
\hline $\begin{array}{l}\text { Phelan } \\
\text { et al }{ }^{66}\end{array}$ & $\begin{array}{l}2014 / \\
\text { J Am Soc } \\
\text { Echocardiogr }\end{array}$ & $8(\mathrm{NA})$ & $\begin{array}{l}\text { Using parametric polar maps of regional longitudinal strain, regional varia- } \\
\text { tions in strain were shown to be an easily recognizable, accurate, and repro- } \\
\text { ducible means of differentiating hypertrophic cardiomyopathy or cardiac } \\
\text { amyloidosis from hypertensive heart disease }\end{array}$ \\
\hline \multicolumn{4}{|c|}{ Prognostic significance of speckle tracking echocardiography } \\
\hline Buss et $a l^{67}$ & $\begin{array}{l}2012 / \\
J\end{array}$ & $206(A L)$ & $\begin{array}{l}\text { In a multivariable echocardiographic Cox model, only diastolic dysfunction } \\
\text { and } 2 \mathrm{D} \text { global longitudinal strain remained as independent predictors of } \\
\text { survival }\end{array}$ \\
\hline Liu et $a^{68}$ & $\begin{array}{l}2013 / \\
\text { PLoS One }\end{array}$ & $44(\mathrm{AL})$ & $\begin{array}{l}\text { Multivariate regression analysis showed that NYHA class and mid-septum } \\
\text { systolic longitudinal strain were independent predictors for survival }\end{array}$ \\
\hline $\begin{array}{l}\text { Quarta } \\
\text { et al } 69\end{array}$ & $\begin{array}{l}2014 / \\
\text { Circulation }\end{array}$ & $\begin{array}{l}80(\mathrm{AL}) / 36(\mathrm{FAP}) / \\
56(\mathrm{SSA})\end{array}$ & $\begin{array}{l}\text { TTR-related causes were favorable predictors of survival, whereas longitudi- } \\
\text { nal strain and advanced NYHA class were negative predictors }\end{array}$ \\
\hline
\end{tabular}

AA, secondary amyloidosis; AL, light-chain amyloidosis; ATTRm, hereditary transthyretin-related amyloidosis; ATTRwt, wild-type transthyretinrelated amyloidosis; 2D, 2-dimensional; ECG, electrocardiography; FAP, familial amyloid polyneuropathy; LV, left ventricular; MM, multiple myeloma; NA, the type of amyloidosis is not available in the report; NYHA, New York Heart Association; RV, right ventricular; SSA, senile systemic amyloidosis; TTR, transthyretin-related.

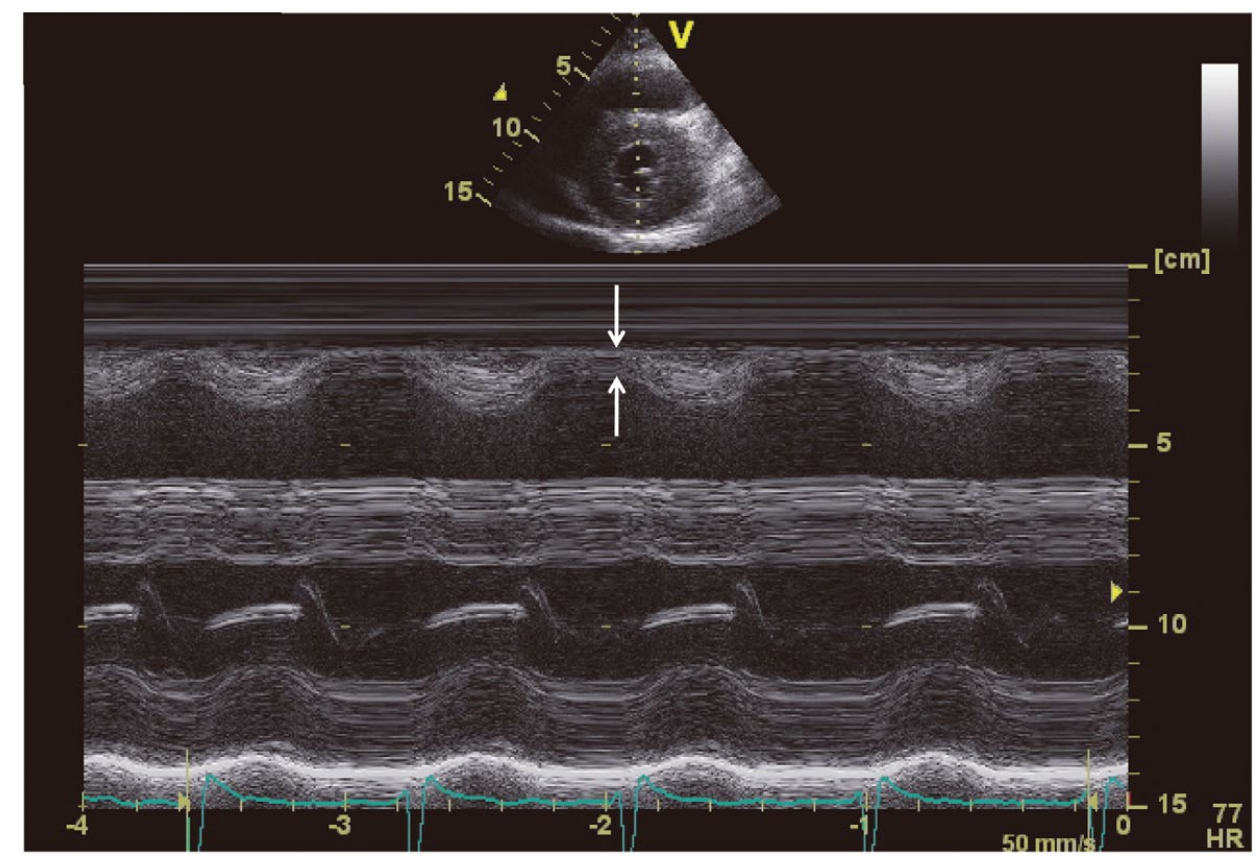

Figure 1. M-mode echocardiography. The right ventricular free wall thickness is increased in addition to left ventricular concentric hypertrophy.

the diagnosis and management of the cardiac amyloidoses. Table is a summary of the studies on the topic.

\section{M-Mode Echocardiography (Figure 1)}

The first description of the echocardiographic characteristics of cardiac amyloidosis was reported by Chew et al in 1975 


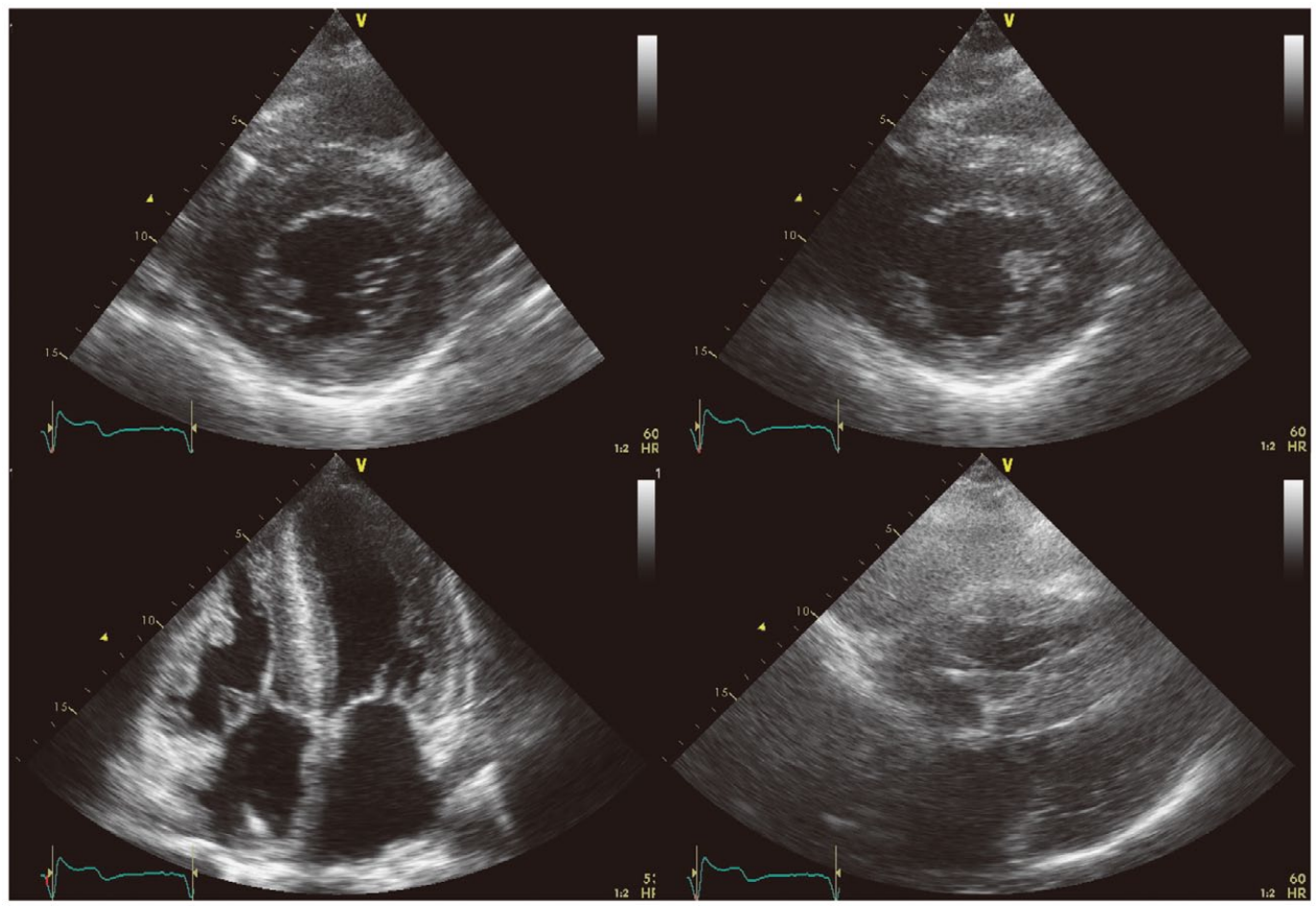

Figure 2. Two-dimensional echocardiography. Thickening of the right, left ventricular, and atrial walls can be seen.

using M-mode echocardiography in 3 cases. $^{6}$ The authors suggested that normal left ventricular (LV) dimensions in diastole, diminished amplitude of excursion, increased systolic dimensions, and pericardial effusion were strongly suggestive of cardiac amyloidosis. Child et al reported on the basic echocardiographic findings in infiltrative cardiomyopathy caused by amyloid, namely (1) symmetrically increased LV wall thickness in the absence of hypertension or aortic valvular disease, (2) hypokinesia and decreased systolic thickening of the interventricular septum and LV posterior wall, and (3) small-to-normal size of the LV cavity. Moreover, 2 of the reported 7 patients showed small pericardial effusions. ${ }^{7}$ In addition to the findings of $\mathrm{LV}$ wall thickening and increased LV mass, the characteristics of infiltrative cardiomyopathy include a septal/posterobasal free wall thickness ratio $<1.3$, increased maximal left atrial transverse dimension, reduced mitral valve closure (E-F) slope, and preserved ejection fraction $(\mathrm{EF})>60 \%$, even before clinically evident heart disease develops. ${ }^{8}$

The right ventricular (RV) anterior wall thickness is reportedly significantly increased in patients with clinically significant amyloid infiltrative cardiomyopathy, and this is consistent with pathologic findings. ${ }^{9,10}$ In conjunction with the LV abnormalities, this finding further prevents clinical or hemodynamic confusion between amyloid cardiomyopathy and constrictive pericardial disease. Further, in 1981, Child et al reported that the mitral E point to ventricular septal separation and its ratio to the LV end-diastolic dimension could accurately separate individuals with normal and abnormal LV function, irrespective of LV size. ${ }^{10}$

Using computer-assisted analysis of M-mode echocardio- grams, patients with cardiac amyloid show characteristic quantitative echocardiographic findings, including (1) normal or small LV cavity size, (2) decreased peak rate of diastolic cavity filling, (3) prolonged isovolumic relaxation, (4) decreased fractional shortening and peak rate of circumferential fiber shortening, and (5) decreased peak rates of both systolic thickening and diastolic thinning of the septum and posterior LV wall. ${ }^{11}$ Interestingly, approximately $75 \%$ reduction in diastolic thinning, compared with 50\% systolic thickening, is reported, indicating greater impairment of the diastolic than systolic regional function.

A necropsy study, which included echocardiography data from the last few months of life in 11 patients with cardiac amyloidosis, indicated that endstage cardiac amyloidosis patients showed thick LV walls (septum thickness: $21.9 \pm 8.1 \mathrm{~mm}$; posterior wall thickness: $20 \pm 4 \mathrm{~mm}$ ), and small LV cavity (41.5 $\pm 10.1 \mathrm{~mm}$ at end-diastole). ${ }^{12}$ Thus, simple M-mode echocardiography provides useful information to differentiate cardiac amyloidosis from other causes of LV hypertrophy, especially when symptoms of congestive heart failure are present.

\section{Two-Dimensional (2D) Echocardiography} (Figure 2)

Siqueira-Filho et al (1981) first reported on the 2D echocardiographic findings in cardiac amyloidosis. ${ }^{13}$ In addition to M-mode examination, 2D echocardiography can reveal additional features such as thickened papillary muscles, thickened valves, better appreciation of the thickened RV wall, and a characteristic "granular sparkling" appearance of the thickened cardiac walls. 


\section{Voltage/Mass Relation}

Carroll et al evaluated 14 systemic amyloidosis patients using electrocardiographic voltage and echocardiographic muscle cross-sectional areas. ${ }^{14}$ The electrocardiographic voltage tended to be low (sum of $\mathrm{S}$ wave in lead V1 plus $\mathrm{R}$ wave in lead V5 or V6 [SV1 $+\mathrm{RV}_{5}$ or $\left.\mathrm{V}_{6}\right]=14.6 \pm 4.8 \mathrm{~mm}$; normal range: $15-35 \mathrm{~mm})$ and the echocardiographic muscle cross-sectional area tended to be increased $\left(11.4 \pm 2.7 \mathrm{~cm}^{2} / \mathrm{m}^{2}\right.$; normal range: $6-10 \mathrm{~cm}^{2} / \mathrm{m}^{2}$ ). When the techniques were combined, an inverse correlation between voltage and muscle cross-sectional area $(\mathrm{r}=-0.79)$ was observed in amyloidosis patients; moreover, a marked derangement of the voltage/cross-sectional area relation was associated with clinical symptoms and mortality.

Further, Simons and Isner compared the relative sensitivity of noninvasive tests (2D echocardiography, computerized tomography, magnetic resonance imaging, electrocardiography, and nuclear scintigraphy) in 15 patients with proven cardiac amyloidosis. ${ }^{15}$ The sensitivity of both myocardial technetium uptake and echocardiographic observation of sparkling was low; however, voltage/mass relation diagrams appeared to represent a promising noninvasive diagnostic method for cardiac amyloidosis. The combination of increased LV thickness and low-voltage electrocardiographic pattern is highly specific for cardiac amyloidosis and was found in 3/30 (10\%) and $13 / 24(54 \%)$ of secondary and AL amyloidosis patients, respectively.

Echocardiography is a sensitive test for the detection of cardiac involvement in amyloidosis, in both symptomatic and asymptomatic patients. ${ }^{16}$ In 1 study, 58 of 196 consecutive patients undergoing endomyocardial biopsy for clinical suspicion of cardiac amyloidosis were confirmed to have the condition; multivariate analysis revealed that a combination of low voltage and increased LV thickness produced the most statistically useful model. ${ }^{17}$

\section{Myocardial Texture Characterization}

Bhandari et al performed myocardial texture characterization by $2 \mathrm{D}$ echocardiography in 181 patients with various cardiac disorders, including 7 with amyloidosis, and 24 controls. ${ }^{18}$ Cardiac amyloidosis was characterized by the presence of very bright or highly refractile echoes in the myocardium. Although all amyloidosis patients showed this pattern, it was also observed in patients with uncomplicated ventricular hypertrophy, chronic renal failure, hypertrophic cardiomyopathy, Pompe disease, hemochromatosis, and left heart hypoplastic syndrome, indicating that this finding is nonspecific.

Among 15 patients with changes in myocardial wall echogenicity on 2D echocardiography, a positive gingival biopsy result for amyloidosis was observed in 11 patients. ${ }^{19}$ Increased myocardial echogenicity reportedly has a sensitivity of $87 \%$ and specificity of $81 \%,{ }^{20}$ whereas the combination of increased myocardial echogenicity and increased atrial thickness showed $60 \%$ sensitivity and $100 \%$ specificity for the diagnosis of amyloidosis. Moreover, quantitative texture measurements of the first order (mean gray level, skewness, kurtosis, energy, and entropy) on 2D echocardiograms overlap between normal subjects and cardiac amyloidosis patients; ${ }^{21}$ among the second-order statistics variables, only entropy was significantly and consistently higher in amyloidosis patients.

\section{Myocardial Scintigraphy and Echocardiography}

Falk et al examined 20 consecutive patients with biopsyproven primary amyloidosis with echocardiography and technetium-99 m-pyrophosphate myocardial scintigraphy. ${ }^{22}$ They found that increased wall thickness correlated with myocardial pyrophosphate uptake; none of the 10 control patients with nonamyloid, nonischemic heart disease had a strongly positive uptake. In another study of 12 FAP patients with echocardiographic abnormalities (highly refractile myocardial echoes, thickened heart valves, and increased heart wall thickness), only 4 patients had abnormal myocardial uptake of technetium-99 m pyrophosphate; thus, cross-sectional echocardiography is superior to technetium-99m pyrophosphate scintigraphy in detecting cardiac involvement in FAP. ${ }^{23}$ Further, the scintigraphy uptake index clearly differs between echocardiographic and nondetectable cardiac amyloidosis. ${ }^{24}$

\section{D Echocardiographic Assessment and Prognosis}

Falk et al reported a correlation between cardiac arrhythmias and echocardiographic abnormalities, as well as heart failure, in systemic amyloidosis. ${ }^{25}$ There were 4 sudden deaths, all in patients with abnormal echocardiograms and complex ventricular arrhythmias. Cueto-Garcia et al showed that the occurrence of clinical congestive heart failure strongly correlated with greater wall thickness and multiple other echocardiographic abnormalities, and that survival was negatively influenced by greater wall thickness and reduced systolic function (fractional shortening), indicating that echocardiographic examination is an important tool for identifying cardiac amyloid involvement and that it may be useful in estimating prognosis in systemic amyloidosis. ${ }^{26}$ Hongo and Ikeda examined 28 patients with FAP by echocardiography. ${ }^{27}$ Their crosssectional study suggested that wall thickness, incidence of granular sparkling appearance, and existence of pericardial effusion positively correlated with neurologic stage, whereas LV end-diastolic dimension, fractional shortening, and mitral valve E-F slope showed inverse correlations. A serial observational study demonstrated that the LV wall thickness was increased, while the E-F slope, fractional shortening, and LV internal diastolic dimension were decreased, in FAP patients, and that amyloid heart disease develops slowly but progressively in these patients.

A low-voltage pattern on electrocardiography and LVEF allows identification of patients at high risk of death. ${ }^{28}$ Dubrey et al demonstrated that late potentials were more frequent in patients with echocardiographic evidence of cardiac amyloidosis $(31 \%)$ compared with patients with normal echocardiograms $(9 \%, \mathrm{P}<0.003),{ }^{29}$ and abnormal and signal-averaged electrocardiograms were both predictive of all-cause $(\mathrm{P}<0.0001)$ and sudden cardiac death $(\mathrm{P}<0.0001)$. Thus, $2 \mathrm{D}$ echocardiographic findings suggestive of advanced-stage cardiac amyloidosis may represent adverse prognostic factors.

\section{Doppler Echocardiography (Figure 3)}

Kinoshita et al first assessed LV diastolic filling in 12 patients with FAP and 15 controls by pulsed Doppler echocardiography. ${ }^{30}$ No patients had clinical evidence of overt heart disease or restrictive cardiomyopathy, and only 2 showed LV wall thickening. The peak flow velocity and acceleration rate of early diastolic filling were lower and the ratio of atrial peak flow velocity/early diastolic peak flow velocity was significantly greater in FAP patients compared with the controls, with the ratio significantly correlating with LV posterior wall thickness.

Klein et al first performed Doppler echocardiographic assessment of LV diastolic function in 64 patients with primary systemic amyloidosis. ${ }^{31}$ In early amyloidosis (mean wall 
Transmitral flow

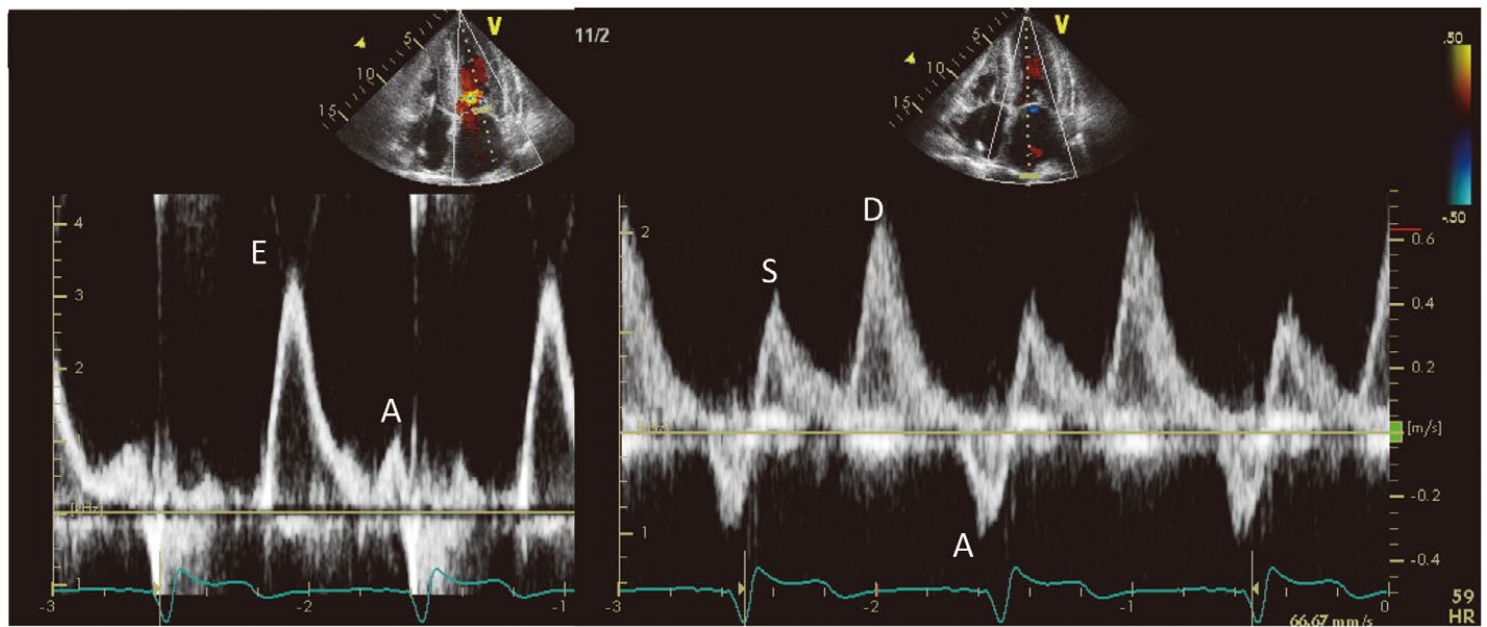

Figure 3. Transmitral and pulmonary venous Doppler flow measurements showing the restrictive pattern of transmitral flow and increased diastolic/systolic flow velocity ratio in advanced cardiac amyloidosis.

thickness $12-15 \mathrm{~mm}$ ), relaxation was abnormal, with decreased peak early velocity, increased late velocity, decreased early/ late velocity ratio, and prolonged isovolumic relaxation time compared with normal values. In advanced amyloidosis (mean LV wall thickness $\geq 15 \mathrm{~mm}$ ), a restrictive filling pattern with a markedly shortened deceleration time, decreased pulmonary vein peak systolic flow, and increased diastolic flow velocity were observed compared with the normal values. Abnormal RV diastolic function by Doppler ultrasound measurements of RV inflow, superior vena cava, and hepatic vein flow velocities with respiratory monitoring have also been reported. ${ }^{32}$

Patients with advanced-stage disease show a markedly shortened deceleration time (restrictive pattern). Serial pulsed wave Doppler studies of LV inflow were performed over 12.6 \pm 4.9 months in 41 consecutive patients with typical 2D echocardiographic features of cardiac involvement; 33 patients in the early group (mean LV thickness $<15 \mathrm{~mm}$ ) showed changes from abnormal relaxation or "normal" patterns to restrictive patterns, which coincided with worsened symptoms in 6 patients; 15 of the 17 patients in the advanced group (mean LV thickness $\geq 15 \mathrm{~mm}$ ) did not show significant changes during the follow-up, but these patients already showed a restrictive pattern.

Dubrey et al reported a comparison of echocardiographic and electrocardiographic features between FAP $(n=12)$ and AL $(n=24)$ cardiac amyloidosis. ${ }^{34}$ The echocardiograms were morphologically indistinguishable, with similar LV and RV wall thicknesses; the Doppler indices of LV and RV function, LV volume, and EF were also similar. Low-voltage electrocardiograms $(<0.5 \mathrm{mV})$ were more common in AL $(67 \%)$ than in FAP $(25 \% ; \mathrm{P}<0.05)$, and the 1 -year survival was $38 \%$ and $92 \%$, respectively, with virtually all deaths being cardiac-related.

Additionally, noninvasively derived left atrial kinetic energy, which is calculated from the formula $1 / 2 \mathrm{mv}^{2}$, where $\mathrm{m}=$ the product of mean left atrial stroke volume (in $\mathrm{cm}^{3}$ ) and blood density $(1.06 \mathrm{~g} / \mathrm{ml})$, and $\mathrm{v}=$ mean transmitral Doppler A-wave velocity $(\mathrm{cm} / \mathrm{s})$, is severely impaired in $\mathrm{AL}$ amyloidosis once ventricular infiltration is apparent on echocardiography. ${ }^{35}$

\section{D/Doppler Echocardiography and Patient Prognosis}

$\mathrm{RV}$ dilatation appears to be associated with more severe involvement and poorer prognosis (median survival, 4 months). ${ }^{36}$ Of multiple clinical, echocardiographic, and Doppler features entered into a multifactorial model, RV dilation (LV/RV area ratio $\leq 2$ ) remained the only independent predictor of survival. Doppler-derived LV diastolic filling variables are also important predictors of survival in cardiac amyloidosis, ${ }^{37}$ with patients with a transmitral early filling wave deceleration time $\leq 150 \mathrm{~ms}$ (indicating a restrictive pattern) showing poor cardiac outcomes.

Tei proposed an easily measured index of myocardial performance, combining systolic and diastolic time intervals, ${ }^{38}$ and then retrospectively examined 45 patients with biopsyproven amyloidosis. ${ }^{39}$ The isovolumetric contraction and relaxation times were prolonged and the ejection time was shortened in amyloidosis patients compared with normal subjects. In the amyloid group, the index was the highest in patients with low stroke index or with both shortened mitral deceleration time and lower EF. In the multivariate analysis, this index, as well as the New York Heart Association (NYHA) functional class, was the only independent predictor of survival.

$\mathrm{Ng}$ et al compared the echocardiographic features and prognoses between SSA $(n=18)$ and AL amyloidosis $(n=18) .{ }^{40}$ SSA was characterized by amyloidosis clinically limited to the heart. In contrast to the rapid progression of heart failure in AL amyloidosis, SSA was found to result in slowly progressive heart failure, despite the thicker LV wall and older age of the patients.

Migrino et al examined 42 biopsy-proven AL amyloidosis patients with echocardiography and followed them for $29 \pm 16$ months. ${ }^{41}$ Among the 2D/Doppler flow (mitral and LV outflow tract flow) and clinical parameters, only ejection time and 


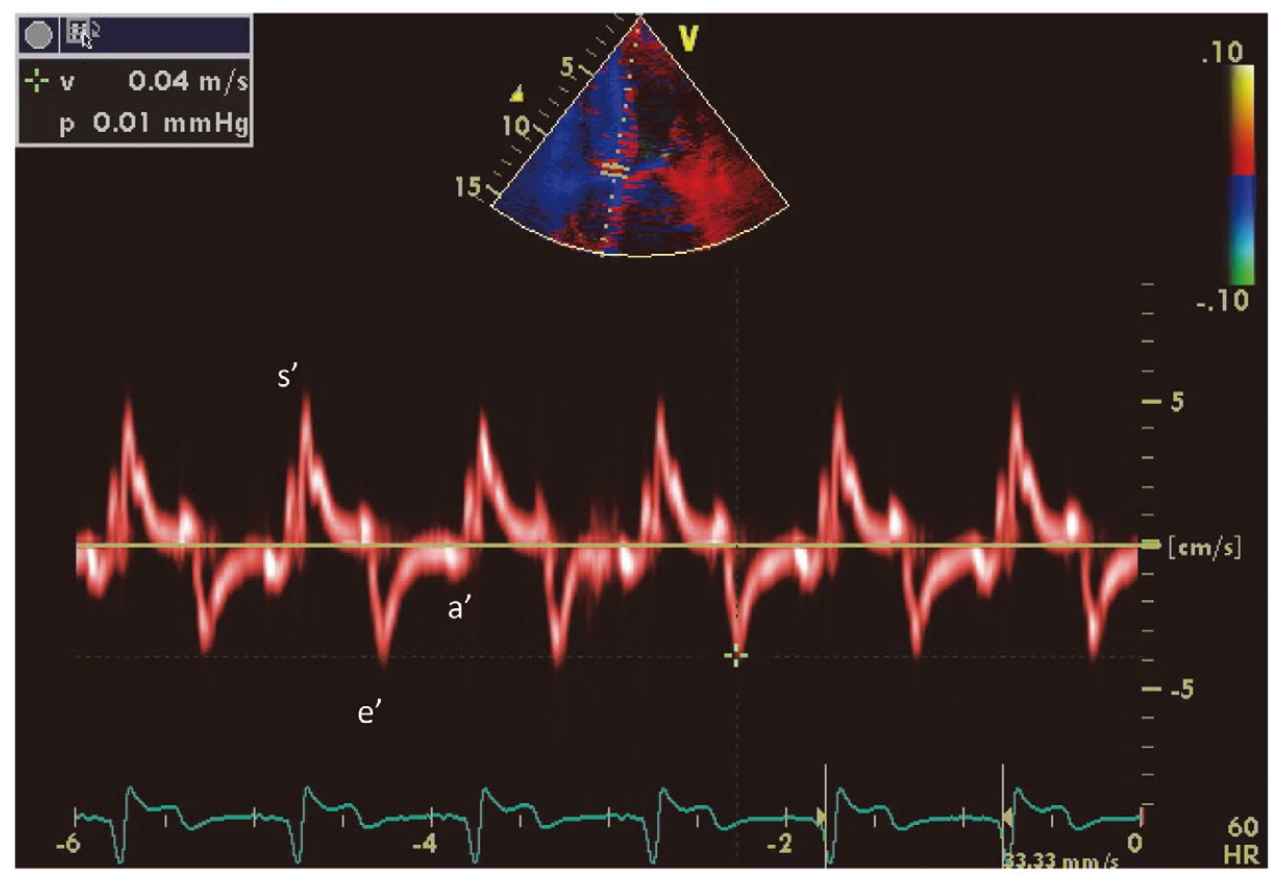

Figure 4. Pulsed tissue Doppler imaging. The systolic and diastolic pulsed tissue Doppler velocities are decreased in advanced cardiac amyloidosis.

alkaline phosphatase showed incremental values to heart failure class in predicting mortality. Rapezzi et al. conducted a longitudinal study of 233 patients with cardiac amyloidoses (AL, $n=157$; ATTRm, $n=61$; ATTRwt, $n=15) .{ }^{42}$ At diagnosis, the mean LV wall thickness was higher in ATTRwt than in ATTRm and AL patients, and the LVEF was moderately depressed in ATTRwt but not in AL or ATTRm. Moreover, ATTRm patients less frequently displayed low voltage/mass ratio and it was a strong favorable predictor of survival, whereas ATTRwt was found to predict freedom from major cardiac events.

Pinney et al compared 102 ATTRwt with 36 isolated AL cases. ${ }^{43}$ ATTRwt patients showed thicker LV walls, lower E/e', and longer transmitral early filling wave deceleration time. Univariate analysis demonstrated that no echocardiographic parameters were associated with survival in ATTRwt.

\section{Pulsed Tissue Doppler Imaging (Figure 4)}

Cardiac amyloidosis is characterized by an initial impairment in early cardiac relaxation, whereas congestive heart failure is associated with an impairment of peak systolic wall motion velocities, most prominently seen in the longitudinal axis. ${ }^{44}$ Moreover, peak lateral and medial mitral annulus velocities and color M-mode tissue Doppler of the LV posterior wall (for measurements of mean myocardial velocities and myocardial velocity gradient) can differentiate cardiac amyloidosis and control patients with a fair overall accuracy. ${ }^{45}$

The longitudinal myocardial velocity gradients, indicating differences between the basal and mid-myocardial velocities, using pulsed tissue Doppler imaging are reportedly significantly impaired in patients with, than without, congestive heart failure. ${ }^{46}$ Conversely, single-point analysis of pulsed tissue
Doppler imaging cannot distinguish between these patients. Furthermore, the LV long-axis function was depressed in all $(100 \%)$ cardiac amyloidosis patients compared with only $36 \%$ of idiopathic restrictive cardiomyopathy patients. ${ }^{47}$ Even when compared with diastolic color Doppler myocardial imaging measurements, standard pulsed wave tissue Doppler imaging of the mitral annulus is the most accurate diastolic measure of early LV dysfunction in patients with AL amyloidosis. ${ }^{48}$

\section{Color-Coded Tissue Doppler Imaging}

The myocardial velocity profile, derived from color-coded tissue Doppler imaging, can differentiate cardiac amyloidosis from other causes of LV hypertrophy. ${ }^{49}$ The percent systolic thickening of the LV septum and posterior wall calculated from M-mode LV echocardiograms is lower in cardiac amyloidosis than in other causes of LV hypertrophy, and the systolic and early diastolic myocardial velocity profiles show characteristic serrated patterns in all patients with cardiac amyloidosis, but not in any other patient groups.

\section{Prognostic Significance of Ultrasound Myocardial Tissue Characterization (Figure 5)}

The prognostic value of cycle-dependent variation of myocardial integrated backscatter was compared with other standard echocardiographic and Doppler flow indices in 208 consecutive biopsy-proven patients with primary cardiac amyloidosis. ${ }^{50}$ Multivariate analysis showed that this parameter at the $\mathrm{LV}$ posterior wall was the only independent predictor of both cardiac and overall deaths. In this study, the Tei index ${ }^{38,39}$ did not correlate with mortality risk. 

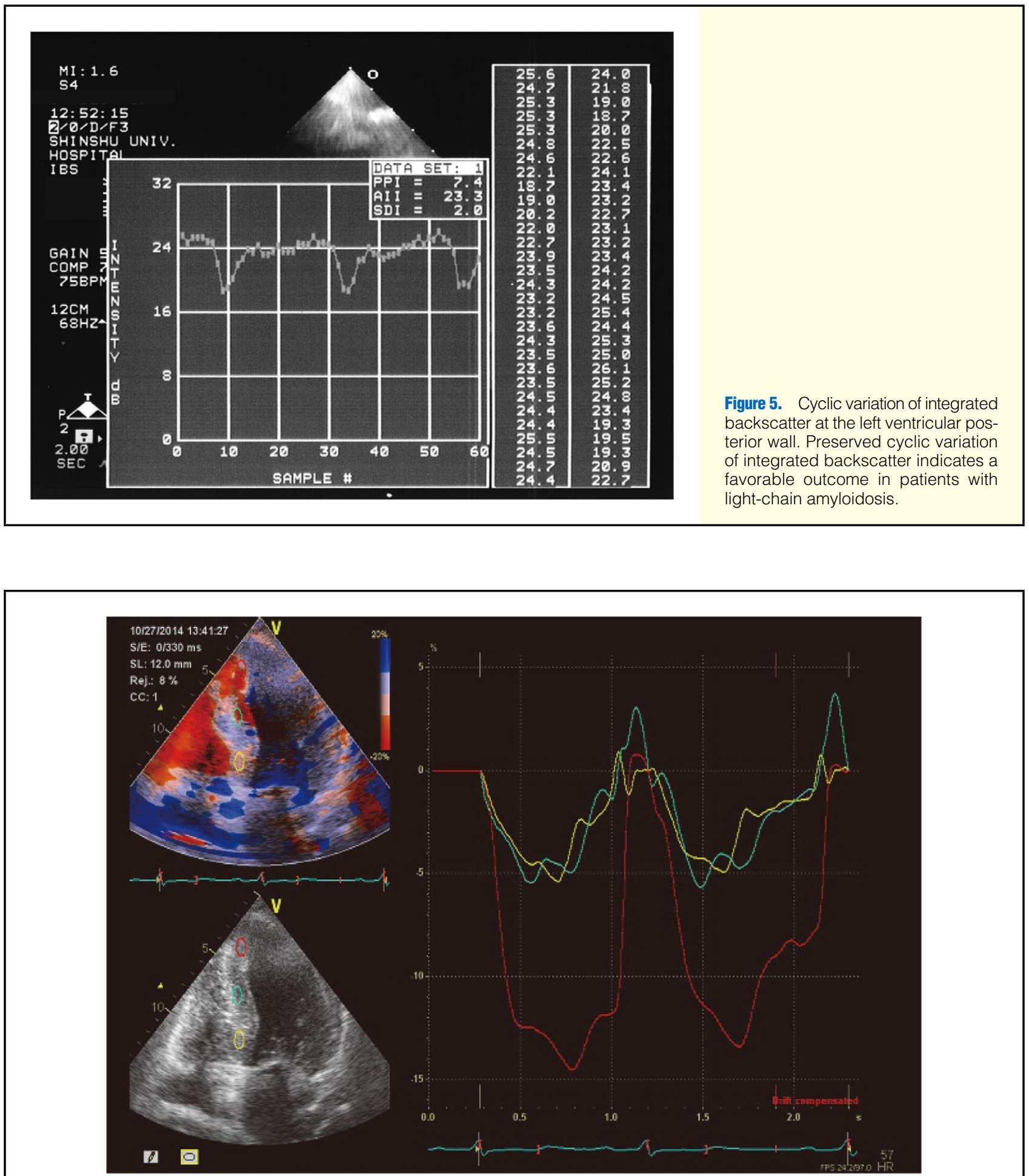

Figure 6. Strain Doppler imaging in a patient with advanced light-chain amyloidosis. Both basal and mid-left ventricular longitudinal strain is impaired, and apical longitudinal strain is preserved.

\section{Strain Doppler Imaging (Figure 6)}

Longitudinal LV myocardial function assessed by strain and strain rate tissue Doppler echocardiography can detect early impairments in systolic longitudinal LV function in AL amyloidosis patients upon fractional shortening, but before it is detectable by tissue velocity imaging. ${ }^{51,52}$ This sensitive method can detect differences in LV function between ATTRm and 

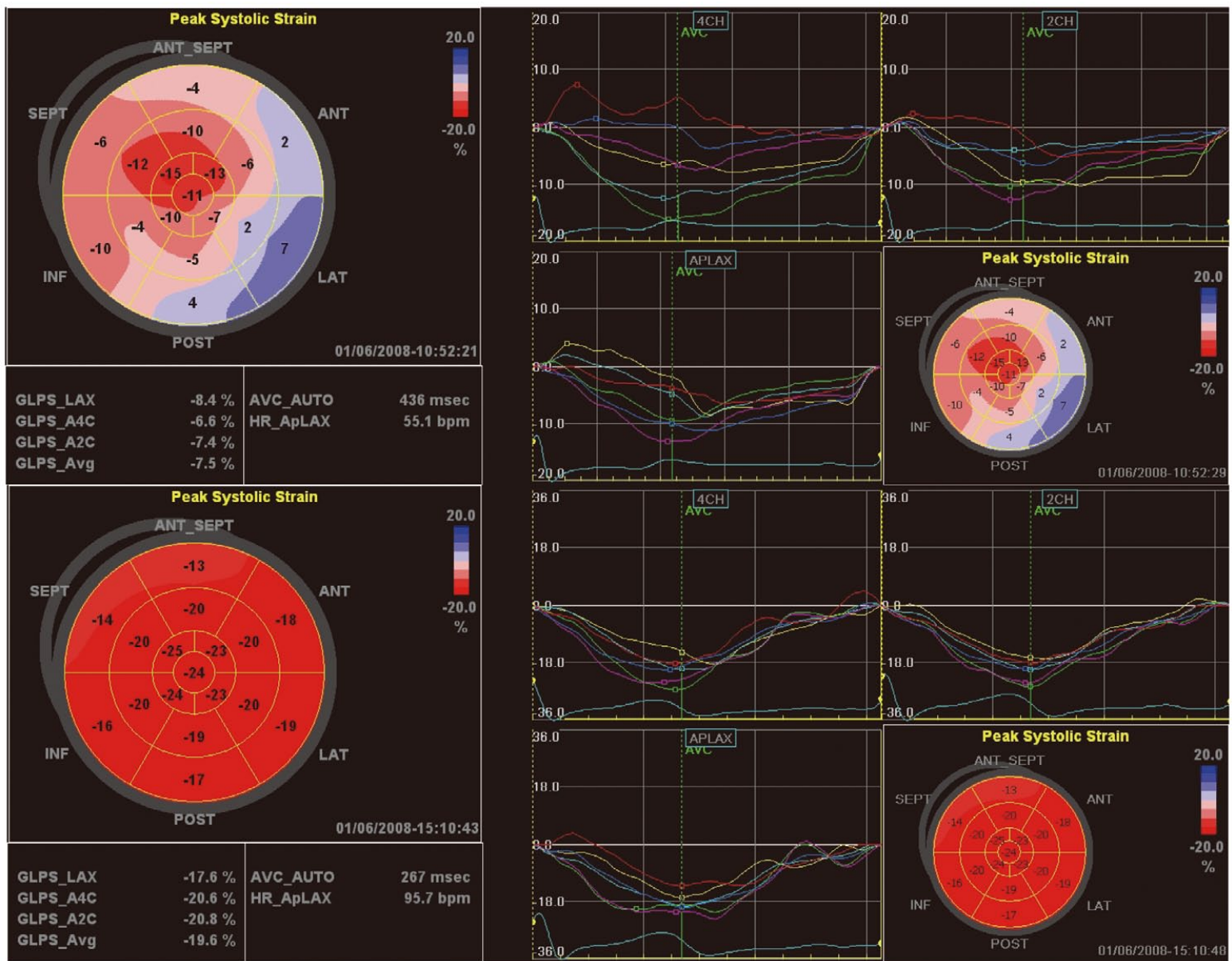

Figure 7. Speckle tracking echocardiography of advanced light-chain amyloidosis (Upper) and no cardiac amyloid (Lower). Apical sparing of longitudinal strain can be seen in advanced cardiac amyloidosis.

AL amyloidosis, which cannot be distinguished by standard echocardiographic parameters, despite the severity of congestive heart failure and cardiac mortality being much lower in ATTRm. ${ }^{53}$ In fact, this method can detect impaired LV systolic function in AL amyloidosis patients with no evidence of cardiac involvement on standard 2D and Doppler echocardiography. ${ }^{54}$

\section{Strain Doppler Imaging as a Prognosticator}

A total of 249 consecutive AL amyloidosis patients were prospectively enrolled to identify independent predictors of survival, compare clinical data, hematologic and cardiac biomarkers, and standard echocardiographic and Doppler myocardial imaging measures. ${ }^{55}$ Multivariate analysis identified NYHA class III or IV, presence of pleural effusion, brain natriuretic peptide level $>493 \mathrm{pg} / \mathrm{ml}$, ejection time $<273 \mathrm{~ms}$, and peak longitudinal systolic basal anteroseptal strain $\geq-7.5 \%$ as poor independent predictors of clinical outcome in these patients. The mean basal LV longitudinal strain was reported to be a powerful predictor of clinical outcome and was superior to standard 2D echocardiographic, Doppler flow measurements, and simple tissue velocity indices. ${ }^{56}$ Additionally, RV function assessed by Doppler myocardial imaging can also identify early impairment of cardiac function and stratify mortality risk in AL amyloidosis patients. ${ }^{57}$

\section{Intracardiac Thrombus in Cardiac Amyloidosis}

Dubrey et al reported 3 rare cases of extensive cardiac amyloidosis with large atrial thrombi in the left atrium during sinus rhythm. ${ }^{58}$ Doppler studies showed no A-wave on mitral inflow. The authors concluded that severe atrial and ventricular infiltration by amyloid may have resulted in mechanical atrial standstill with resultant thrombus formation, and that such patients may require anticoagulation therapy when atrial function is impaired.

Feng et al reported on 116 autopsy or explanted cases of cardiac amyloidosis (55 AL, 61 others) examined for intracardiac thrombus. ${ }^{59}$ Intracardiac thrombosis was identified in 38 hearts $(33 \%)$. The AL group had significantly more intracardiac thrombi and fatal embolic events, despite being younger and having less atrial fibrillation. Multivariate analysis demonstrated that AL type and LV diastolic dysfunction were independently associated with the risk of thromboembolism. In another study by the same group, transthoracic and transesophageal echocardiograms of 156 patients with cardiac 
amyloidosis (80 AL, 76 others) were studied; ${ }^{60} 58$ intracardiac thrombi were identified in 42 patients $(27 \%)$. Multivariate analysis showed that atrial fibrillation, poor LV diastolic function, and lower left atrial appendage emptying velocity were independent risk factors for intracardiac thrombosis, whereas anticoagulation was associated with a significantly decreased risk.

\section{Speckle Tracking Echocardiography (Figure 7)}

Modesto et al compared 2D and tissue Doppler-derived strain echocardiographic measurements in amyloid cardiomyopathy patients and age-matched healthy volunteers; ${ }^{61}$ they found that the 2D strain echocardiography values correlated closely with the tissue Doppler-derived strain echocardiography values ( $r=0.94$ and 0.96 for strain rate and strain, respectively).

Speckle tracking echocardiographic measurement of myocardial strain and strain rate can discriminate cardiac amyloidosis from other causes of cardiac hypertrophy. ${ }^{62}$ Cardiac amyloid profoundly alters all strain parameters (longitudinal, circumferential, and radial strain) compared with other causes of LV hypertrophy. In one study, endocardial and epicardial longitudinal and circumferential strain and radial strain were found to be significantly lower in hypertrophic cardiomyopathy and ATTR cardiac amyloidosis patients compared with control subjects. ${ }^{63}$ Further, epicardial circumferential strain was significantly lower in ATTR cardiac amyloidosis than in hypertrophic cardiomyopathy. The peak systolic radial strain and strain rate have been reported to be indicative of LV segments with cardiac amyloidosis involvement, as confirmed by cardiac magnetic resonance imaging in a patient with secondary amyloidosis. ${ }^{64} \mathrm{~A}$ systolic septal longitudinal base-to-apex strain gradient (septal apical/basal longitudinal systolic ratio $>2.1$ ), combined with a shortened diastolic deceleration time of early filling (deceleration time of early filling $<200 \mathrm{~ms}$ ), aids in differentiating cardiac amyloidosis from other causes of concentric LV hypertrophy. ${ }^{65}$ Using parametric polar maps of regional longitudinal strain, regional variations in strain are easily recognizable, and represent an accurate and reproducible means of differentiating hypertrophic cardiomyopathy or cardiac amyloidosis from hypertensive heart disease.$^{66}$

\section{Prognostic Significance of Speckle Tracking Echocardiography}

The echocardiographic imaging parameters, mean tissue Doppler-derived and 2D global longitudinal strains of the LV, cardiac serological biomarkers, and comprehensive clinical characteristics were prospectively assessed in 206 consecutive patients with biopsy-proven systemic AL amyloidosis. ${ }^{67}$ In the multivariate analysis, only diastolic dysfunction and 2D global longitudinal strain remained as independent predictors of survival. Liu et al assessed the LV longitudinal, circumferential, and radial systolic strains by speckle tracking imaging in 44 biopsy-proven systemic AL amyloidosis patients with LV hypertrophy and 30 normal controls. ${ }^{68}$ The EF was preserved but the longitudinal systolic strain was significantly reduced in both compensated and decompensated AL amyloidosis patients. The longitudinal systolic strains were similar in the apical segments and significantly reduced in the basal segments in both groups, and multivariate analysis showed that NYHA class and mid-septum systolic longitudinal strain were independent predictors for survival.

Quarta et al analyzed 172 patients with cardiac amyloidoses (80 AL, 36 ATTRm, 56 ATTRwt) by standard echocardiography and 2D speckle tracking imaging-derived LV longitudinal, radial, and circumferential strains. ${ }^{69}$ Compared with ATTRm and AL amyloidosis, ATTRwt was characterized by greater LV wall thickness and lower EF, and the LV longitudinal strain was more depressed in both ATTRwt and AL amyloidosis. TTR-related causes were favorable predictors of survival, whereas longitudinal strain and advanced NYHA class were negative predictors.

\section{Conclusions}

Recent advances in echocardiography allow noninvasive measurement of cardiac function, and novel echocardiographic parameters may represent prognosticators, especially in AL amyloidosis. The LV longitudinal function and the cyclic variation of myocardial integrated backscatter may be the best predictors of adverse outcome by multivariable echocardiographic Cox models..$^{50,55,56,67}$ Newer echocardiographic techniques such as 3-dimensional echocardiography or strain echocardiography are expected to add further useful information for assessing cardiac function and prognosis in cardiac amyloidosis patients. ${ }^{70-72}$

Finally, we pay our respects to the achievements of our predecessors.

\section{Disclosures}

Financial Support: None.

\section{References}

1. Falk RH, Comenzo RL, Skinner M. The systemic amyloidoses. $N$ Eng J Med 1997; 337: 898-909.

2. Merlini G, Bellotti V. Molecular mechanisms of amyloidosis. $N$ Engl J Med 2003; 349: 583-596.

3. Ruberg FL, Berk JL. Transthyretin (TTR) cardiac amyloidosis. Circulation 2012; 126: 1286-1300.

4. Koike H, Misu K, Ikeda S, Ando Y, Nakazato M, Ando E, et al; Study Group for Hereditary Neuropathy in Japan. Type I (transthyetin Met30) familial amyloid polyneuropathy in Japan: Early- vs late-onset form. Arch Neurol 2002; 59: 1771-1776.

5. Koike H, Sobue G. Late-onset familial amyloid polyneuropathy in Japan. Amyloid 2012; 19: 55-57.

6. Chew C, Ziady GM, Raphael MJ, Oakley CM. The functional defect in amyloid heart disease: The "stiff heart" syndrome. Am J Cardiol 1975; 36: 438-444.

7. Child JS, Levisman JA, Abbasi AS, MacAplin RN. Echocardiographic manifestations of infiltrative cardiomyopathy: A report of seven cases due to amyloid. Chest 1976; 70: 726-731.

8. Borer JS, Henry WL, Epstein SE. Echocardiographic observations in patients with systemic infiltrative disease involving the heart. Am J Cardiol 1977; 39: 184-188.

9. Child JS, Krivokapich J, Abbasi AS. Increased right ventricular thickness on echocardiography in amyloid infiltrative cardiomyopathy. Am J Cardiol 1979; 44: 1391-1395.

10. Child JS, Krivokapich J, Perloff JK. Effect of left ventricular size on mitral E point to ventricular septal separation in assessment of cardiac performance. Am Heart J 1981; 101: 797-805.

11. St John Sutton MG, Reichek N, Kastor JA, Giuliani ER. Computerized M-mode echocardiographic analysis of left ventricular dysfunction in cardiac amyloid. Circulation 1982; 66: 790-799.

12. Roberts WC, Waller BF. Cardiac amyloidosis causing cardiac dysfunction: Analysis of 54 necropsy patients. Am J Cardiol 1983; 52: $137-146$.

13. Siqueira-Filho AG, Cunha CL, Tajik AJ, Seward JB, Schattenberg TT, Giuliani ER. M-mode and two-dimensional echocardiographic features in cardiac amyloidosis. Circulation 1981; 63: 188-196.

14. Carroll JD, Gaasch WH, McAdam KP. Amyloid cardiomyopathy: Characterization by distinctive voltage/mass relation. Am J Cardiol 1982; 49: 9-13.

15. Simons M, Isner JM. Assessment of relative sensitivities of noninvasive tests for cardiac amyloidosis in documented cardiac amyloidosis. Am J Cardiol 1992; 69: 425-427.

16. Hamer JP, Janssen S, van Rijswijk MH, Lie KI. Amyloid cardiomyopathy in systemic non-hereditary amyloidosis: Clinical, echocardiographic and electrocardiographic findings in 30 patients with AA and 
24 patients with AL amyloidosis. Eur Heart J 1992; 13: 623-627.

17. Rahman JE, Helou EF, Gelzer-Bell R, Thompson RE, Kuo C, Rodriguez ER, et al. Noninvasive diagnosis of biopsy-proven cardiac amyloidosis. J Am Coll Cardiol 2004; 43: 410-415.

18. Bhandari AK, Nanda NC. Myocardial texture characterization by two-dimensional echocardiography. Am J Cardiol 1983; 51: $817-$ 825 .

19. Nicolosi GL, Pavan D, Lestuzzi C, Burelli C, Zardo F, Zanuttini D. Prospective identification of patients with amyloid heart disease by two-dimensional echocardiography. Circulation 1984; 70: 432-437.

20. Falk RH, Plehn JF, Deering T, Schick EC Jr, Boinay P, Rubinow A, et al. Sensitivity and specificity of the echocardiographic features of cardiac amyloidosis. Am J Cardiol 1987; 59: 418-422.

21. Pinamonti B, Picano E, Ferdeghini EM, Lattanzi F, Slavich G, Landini $\mathrm{L}$, et al. Quantitative texture analysis in two-dimensional echocardiography: Application to the diagnosis of myocardial amyloidosis. J Am Coll Cardiol 1989; 14: 666-671.

22. Falk RH, Lee VW, Rubinow A, Hood WB Jr, Cohen AS. Sensitivity of technetium-99 m-pyrophosphate scintigraphy in diagnosing cardiac amyloidosis. Am J Cardiol 1983; 51: 826-830.

23. Eriksson P, Backman C, Bjerle P, Eriksson A, Holm S, Olofsson BO. Non-invasive assessment of the presence and severity of cardiac amyloidosis: A study in familial amyloidosis with polyneuropathy by cross sectional echocardiography and technetium- $99 \mathrm{~m}$ pyrophosphate scintigraphy. Br Heart J 1984; 52: 321 -326.

24. Fournier C, Grimon G, Rinaldi JP, Terral A, Boujon B, Adams D, et al. Usefulness of technetium- $99 \mathrm{~m}$ pyrophosphate myocardial scintigraphy in amyloid polyneuropathy and correlation with echocardiography. Am J Cardiol 1993; 72: 854-857.

25. Falk RH, Rubinow A, Cohen AS. Cardiac arrhythmias in systemic amyloidosis: Correlation with echocardiographic abnormalities. $J$ Am Coll Cardiol 1984; 1: 107-113.

26. Cueto-Garcia L, Reeder GS, Kyle RA, Wood DL, Seward JB, Naessens J, et al. Echocardiographic findings in systemic amyloidosis: Spectrum of cardiac involvement and relation to survival. $J \mathrm{Am}$ Coll Cardiol 1985; 6: 737-743.

27. Hongo M, Ikeda S. Echocardiographic assessment of the evolution of amyloid heart disease: A study with familial amyloid polyneuropathy. Circulation 1986; 73: 249-256.

28. Kristen AV, Perz JB, Schonland SO, Hegenbart U, Schnabel PA, Kristen $\mathrm{JH}$, et al. Non-invasive predictors of survival in cardiac amyloidosis. Eur J Heart Fail 2007; 9: 617-624.

29. Dubrey SW, Bilazarian S, LaValley M, Reisinger J, Skinner M, Falk RH. Signal-averaged electrocardiography in patients with AL (primary) amyloidosis. Am Heart J 1997; 134: 994-1001.

30. Kinoshita O, Hongo M, Yamada H, Misawa T, Kono J, Okubo S, et al. Impaired left ventricular diastolic filling in patients with familial amyloid polyneuropathy: A pulsed Doppler echocardiographic study. Br Heart J 1989; 61: 198-203.

31. Klein AL, Hatle LK, Burstow DJ, Seward JB, Kyle RA, Bailey KR, et al. Doppler characterization of left ventricular diastolic function in cardiac amyloidosis. J Am Coll Cardiol 1989; 13: 1017-1026.

32. Klein AL, Hatle LK, Burstow DJ, Taliercio CP, Seward JB, Kyle RA, et al. Comprehensive Doppler assessment of right ventricular diastolic function in cardiac amyloidosis. J Am Coll Cardiol 1990; 15: $99-108$.

33. Klein AL, Hatle LK, Taliercio CL, Tayler CL, Kyle RA, Bailey KR, et al. Serial Doppler echocardiographic follow-up of left ventricular diastolic function in cardiac amyloidosis. J Am Coll Cardiol 1990; 16: $1135-1141$.

34. Dubrey SW, Cha K, Skinner M, LaValley M, Falk RH. Familial and primary (AL) cardiac amyloidosis: Echocardiographically similar diseases with distinctly different clinical outcomes. Heart 1997; 78: $74-82$.

35. Murphy L, Falk RH. Left atrial kinetic energy in AL amyloidosis: Can it detect early dysfunction? Am J Cardiol 2000; 86: 244-246.

36. Patel AR, Dubrey SW, Mendes LA, Skinner M, Cupples A, Falk RH, et al. Right ventricular dilation in primary amyloidosis: An independent predictor of survival. Am J Cardiol 1997; 80: 486-492.

37. Klein AL, Hatle LK, Taliercio CP, Oh JK, Kyle RA, Gertz MA, et al. Prognostic significance of Doppler measures of diastolic function in cardiac amyloidosis: A Doppler echocardiography study. Circulation 1991; 83: 808-816.

38. Tei C. New non-invasive index for combined systolic and diastolic ventricular function. J Cardiol 1995; 26: 135-136.

39. Tei C, Dujardin KS, Hodge DO, Kyle RA, Tajik AJ, Seward JB. Doppler index combining systolic and diastolic myocardial performance: Clinical value in cardiac amyloidosis. J Am Coll Cardiol 1996; 28 : $658-664$.

40. Ng B, Connors LH, Davidoff R, Skinner M, Falk RH. Senile sys- temic amyloidosis presenting with heart failure: A comparison with light chain-associated amyloidosis. Arch Intern Med 2005; 165: $1425-1429$.

41. Migrino RQ, Mareedu RK, Eastwood D, Bowers M, Harmann L, Hari P. Left ventricular ejection time on echocardiography predicts long-term mortality in light chain amyloidosis. J Am Soc Echocardiogr 2009; 22: 1396-1402.

42. Rapezzi C, Merlini G, Quarta CC, Riva L, Longhi S, Leone O, et al. Systemic cardiac amyloidoses: Disease profiles and clinical courses of the 3 main types. Circulation 2009; 120: 1203-1212.

43. Pinney JH, Whelan CJ, Petrie A, Dungu J, Banypersad SM, Sattianayagam P, et al. Senile systemic amyloidosis: Clinical features at presentation and outcome. $J$ Am Heart Assoc 2013; 2: e000098, doi:10.1161/JAHA.113.000098.

44. Koyama J, Ray-Sequin PA, Davidoff R, Falk RH. Usefulness of pulsed tissue Doppler imaging for evaluating systolic and diastolic left ventricular function in patients with AL (primary) amyloidosis. Am J Cardiol 2002; 89: 1067-1071.

45. Palka P, Lange A, Donnelly JE, Scalia G, Burstow DJ, Nihoyannopoulos P. Doppler tissue echocardiographic features of cardiac amyloidosis. $J$ Am Soc Echocardiogr 2002; 15: 1353-1360.

46. Koyama J, Davidoff R, Falk RH. Longitudinal myocardial velocity gradient derived from pulsed Doppler tissue imaging in AL amyloidosis: A sensitive indicator of systolic and diastolic dysfunction. $J$ Am Soc Echocardiography 2004; 17: 36-44.

47. Perugini E, Rappezi C, Reggiani LB, Poole-Wilson P, Branzi A, Henein MY. Comparison of ventricular long-axis function in patients with cardiac amyloidosis versus idiopathic restrictive cardiomyopathy. Am J Cardiol 2005; 95: 146-149.

48. Al-Zahrani GB, Bellavia D, Pellikka PA, Dispenzieri A, Hayman $\mathrm{SR}$, Oh JK, et al. Doppler myocardial imaging compared to standard two-dimensional and Doppler echocardiography for assessment of diastolic function in patients with systemic amyloidosis. J Am Soc Echocardiogr 2009; 22: 290-298.

49. Oki T, Tanaka H, Yamada H, Tabata T, Oishi Y, Ishimoto T, et al. Diagnosis of cardiac amyloidosis based on the myocardial velocity profile in the hypertrophied left ventricular wall. Am J Cardiol 2004: 93: $864-869$.

50. Koyama J, Ray-Sequin PA, Falk RH. Prognostic significance of ultrasound myocardial tissue characterization in patients with cardiac amyloidosis. Circulation 2002; 106: 556-561.

51. Koyama J, Ray-Sequin PA, Falk RH. Longitudinal myocardial function assessed by tissue velocity, strain, and strain rate tissue Doppler echocardiography in patients with $\mathrm{AL}$ (primary) cardiac amyloidosis. Circulation 2003; 107: 2446-2452.

52. Bellavia D, Abraham TP, Pellikka PA, Al-Zahrani GB, Dispenzieri A, Oh JK, et al. Detection of left ventricular systolic dysfunction in cardiac amyloidosis with strain rate echocardiography. J Am Soc Echocardiogr 2007; 20: 1194-1202.

53. Ogiwara F, Koyama J, Ikeda S, Kinoshita O, Falk RH. Comparison of the strain Doppler echocardiographic features of familial amyloid polyneuropathy (FAP) and light-chain amyloidosis. Am J Cardiol 2005; 95: 538-540.

54. Bellavia D, Pellikka PA, Abraham TP, Al-Zahrani GB, Disoenzieri A, Oh JK, et al. Evidence of impaired left ventricular systolic function by Doppler myocardial imaging in patients with systemic amyloidosis and no evidence of cardiac involvement by standard two-dimensional and Doppler echocardiography. Am J Cardiol 2008; 101: $1039-1045$.

55. Bellavia D, Pellikka PA, Al-Zahrani GB, Abraham TP, Dispenzieri A, Miyazaki C, et al. Independent predictors of survival in primary systemic ( $\mathrm{Al}$ ) amyloidosis, including cardiac biomarkers and left ventricular strain imaging: An observational cohort study. J Am Soc Echocardiogr 2010; 23: 643-652.

56. Koyama J, Falk RH. Prognostic significance of strain Doppler imaging in light-chain amyloidosis. JACC Cardiovasc Imaging 2010; 3: 333-342.

57. Bellavia D, Pellikka PA, Dispenzieri A, Scott CG, Al-Zahrani GB, Grogan M, et al. Comparison of right ventricular longitudinal strain imaging, tricuspid annular plane systolic excursion, and cardiac biomarkers for early diagnosis of cardiac involvement and risk stratification in primary systematic (AL) amyloidosis: A 5-year cohort study. Eur Heart J Cardiovasc Imaging 2012; 8: 680-689.

58. Dubrey S, Pollak A, Skinner M, Falk RH. Atrial thrombi occurring during sinus rhythm in cardiac amyloidosis: Evidence for atrial electromechanical dissociation. Br Heart J 1995; 74: 541-544.

59. Feng D, Edwards WD, Oh JK, Chandrasekaran K, Grogan M, Martinez MW, et al. Intracardiac thrombosis and embolism in patients with cardiac amyloidosis. Circulation 2007; 116: 2420-2426.

60. Feng D, Syed IS, Martinez M, Oh JK, Jaffe AS, Grogan M, et al. 
Intracardiac thrombosis and anticoagulation therapy in cardiac amyloidosis. Circulation 2009; 119: 2490-2497.

61. Modesto KM, Cauduro S, Dispenzieri A, Khandheria B, Belohlavek $\mathrm{M}$, Lysyansky P, et al. Two-dimensional acoustic pattern derived strain parameters closely correlate with one-dimensional tissue Doppler derived strain measurements. Eur J Echocardiogr 2006; 7: 315-321.

62. Sun JP, Stewart WJ, Yang XS, Donnell RO, Leon AR, Felner JM, et al. Differentiation of hypertrophic cardiomyopathy and cardiac amyloidosis from other causes of ventricular wall thickening by twodimensional strain imaging echocardiography. Am J Cardiol 2009; 103: $411-415$.

63. Di Bella G, Minutoli F, Pingitore A, Zito C, Mazeo A, Aquaro GD, et al. Endocardial and epicardial deformations in cardiac amyloidosis and hypertrophic cardiomyopathy. Circ J 2011; 75: 1200-1208.

64. Kusunose K, Yamada H, Iwase T, Nishio S, Tomita N, Niki T, et al. Images in cardiovascular medicine: Cardiac magnetic resonance imaging and 2-dimensional speckle tracking echocardiography in secondary cardiac amyloidosis. Circ J 2010; 74: 1494-1496.

65. Liu D, Hu K, Niemann M, Herrmann S, Cikes M, Störk S, et al. Effect of combined systolic and diastolic functional parameter assessment for differentiation of cardiac amyloidosis from other causes of concentric left ventricular hypertrophy. Circ Cardiovasc Imaging 2013; 6: 1066-1072.

66. Phelan D, Thavendieanathan P, Popovic Z, Collier P, Griffin B, Thomas JD, et al. Application of parametric display of two-dimensional speckle-tracking longitudinal strain to improve the etiologic diagnosis of mild to moderate left ventricular hypertrophy. J Am Soc Echocardiogr 2014; 27: 888-895.

67. Buss SJ, Emami M, Mereles D, Korosoglou G, Kristen AV, Voss A, et al. Longitudinal left ventricular function for prediction of survival in systemic light-chain amyloidosis: Incremental value compared with clinical biochemical markers. J Am Coll Cardiol 2012; 60: $1067-1076$.

68. Liu D, Hu K, Niemann M, Herrmann S, Cikes M, Störk S, et al. Impact of regional left ventricular function on outcome for patients with AL amyloidosis. PLoS One 2013; 8: e56923, doi:10.1371/ journal.pone.0056923.

69. Quarta CC, Solomon SD, Uraizee I, Kruger J, Longhi S, Ferlito M, et al. Left ventricular structure and function in transthyretin-related versus light-chain cardiac amyloidosis. Circulation 2014; 129: $1840-1849$.

70. Seo Y, Ishizu T, Atsumi A, Kawamura R, Aonuma K. Three-dimensional speckle tracking echocardiography. Circ J 2014; 78: 12901301.

71. Seo Y, Yamasaki H, Kawamura R, Ishizu T, Igarashi M, Sekiguchi $\mathrm{Y}$, et al. Left ventricular activation imaging by 3-dimensional speckle-tracking echocardiography: Comparison with electrical activation mapping. Circ J 2013; 77: 2481-2489.

72. Atsumi A, Ishizu T, Kameda Y, Yamamoto M, Harimura Y, Machino-Ohtsuka T, et al. Application of 3-dimensional speckle tracking imaging to the assessment of right ventricular regional deformation. Circ J 2013; 77: 1760-1768. 